\title{
Addition of toasted baru nut (Dypteryx alata Vog.) and extruded rice bran to sugar cane candy ("rapadura")
}

\author{
Célia Caroline Florindo da SILVA ${ }^{1}$, Giselle de Lima Paixão e SILVA ${ }^{1}$, Manoel Soares SOARES JÚNIOR ${ }^{1}$, \\ Adelaide Del Pino BELÉIA², Márcio CALIARI
}

\begin{abstract}
Different proportions of sugar cane juice, toasted baru nut and extruded rice bran were used in the formulation of sugar cane candies ("rapaduras"), and the effect on color, hardness and proximate composition determined. The best formulation was selected on the basis of composition, hardness and luminosity, and evaluated for sensory acceptance and purchase intent. Simplex design was used to plan the experiment and the limits of the different ingredients. Sugar cane juice has lower values for ash, protein, lipids and total fiber compared to the other ingredients, but it is the ingredient that characterizes the product. The added ingredients affect the physical and chemical characteristics of the "rapaduras". The hardness of the experimental

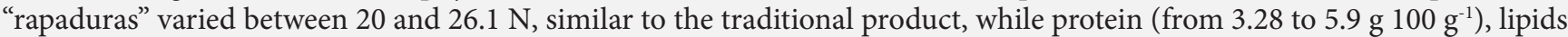

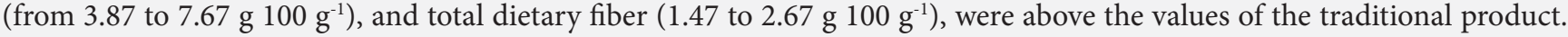

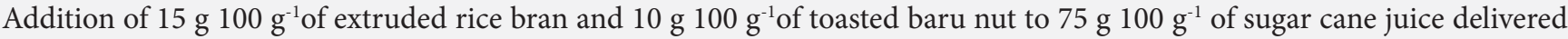
a product with low microbiological risk and good sensory acceptance. The developed product with extruded rice bran and toasted baru nut has good technological potential, allied with sensory and nutritional advantages, and it can be an alternative to add value to rice by-product and nuts from areas of forest conservation.
\end{abstract}

Keywords: Saccharum officinale; Oryza sativa L.; by-product; acceptance; nutrients.

Practical Application: Increasing the nutritional value of sugar cane candy with the addition of extruded rice bran and toasted baru nuts.

\section{Introduction}

The sugar cane candy "rapadura" is a natural sweetener made of unrefined dehydrated sugar cane juice, which is patterned in the form of a brick (Silva et al., 2011). "Rapadura" is produced in Latin America, the Caribbean, Asia and Africa, and the composition depends on cane varieties, as well as on agronomical and processing conditions (Maria, 2013). In Brazil this foodstuff production is the main source of income for farming families, especially in the northeast of the country (Rodriguez et al., 2007).

"Rapadura" contain mainly sucrose and other components in small quantities, such as water, ashes and insoluble proteins. The high energetic value and the presence of minerals and vitamins explain the nutritional benefits of the product (Guerra \& Mujica, 2010). In this context, the enrichment of the "rapadura" with grain by-products and nuts is a very interesting method of increasing the nutritional value and diversifying the flavor for consumers.

The baru tree (Dypterix alata Vog.) is a plant from the Brazilian savanna, and baru nuts have regional importance because of their nutritional content. The baru nut contains high values of unsaturated fatty acids $(\dot{\omega}-6, \dot{\omega}-3)$, vitamin E, zinc, tannin and phytate (Sousa et al., 2011; Marin et al., 2009; Maranhão et al.,

2011; Siqueira et al., 2012). Bento et al. (2014) reported the beneficial effects of these bioactive components in combating to the oxidative stress and contributing to reducing the risk of cardiovascular diseases. Considering the nutritional properties and healthy claims, the consumption of nuts and seeds should be stimulated (Freitas \& Naves, 2010).

Rice bran is one of the by-products of rice milling, which represents about $8 \%$ of the rice grain. It has gained increasing attention worldwide due to its beneficial nutritional and biological effects. The addition of rice bran high in dietary fiber that has a therapeutic potential for the health of the consumers, can contribute to the development of value-added foods or functional foods that are currently in high demand (Friedman, 2013; Gul et al., 2015). However, rice bran is presently underused due to its poor flavor and solubility (Liu et al., 2017). The disagreeable savor could be reduced by the strong taste of baru nut. Furthermore, rice bran has natural enzymes that hydrolyze triglycerides to free fatty acids, which produces a rancid flavor. Thus, the extrusion of rice bran minimized the production of free fatty acids (Lacerda et al., 2013). This agro-industrial by-product is of low cost and could be an option for the rice industry to aggregate 
value to "rapadura" and to feed poor populations through its addition to basic-needs care package (Silva et al., 2016).

The aim of this study was to evaluate the effect of ingredient content (sugar cane juice, toasted baru nut and extruded rice bran) on color, hardness and chemical composition of the sugar cane candies "rapaduras" to determine the higher desirable formulation, and to evaluate sensory acceptance and purchase intent of the selected candy.

\section{Materials and methods}

The sugar cane juice (SJ) was obtained by milling stems, which were mechanically harvested. The cane used was from the RB855536 cultivar, donated by Santa Rita Farm, situated in the municipality of Vianópolis, Goiás State, Brazil, with $17^{\circ}$ Brix. The rice bran, from the IRGA-417 cultivar, was donated by Cristal Foods, situated in municipality of Aparecida de Goiânia, Goiás State, Brazil. Toasted baru nut (TBN) was acquired in Goiânia city, Goiás State, Brazil. They were peeled manually and powdered in a multiprocessor (Faet, Multipractic MC-5, São Paulo, Brazil). The standard "rapadura" was processed with the same technique as the experimental "rapaduras".

\subsection{Formulation and processing of sugar cane candies "rapadura"}

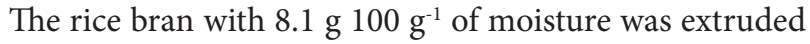
in a single screw equipament (Inbramaq, PQ30, Ribeirão Preto, Brazil), with temperature in the first zone of $40^{\circ} \mathrm{C}$, in the second zone of $60^{\circ} \mathrm{C}$ and in the third zone of $90^{\circ} \mathrm{C}$. A screw of $300 \mathrm{~mm}$ long, compression ratio of 3:1, and speed of $100 \mathrm{~Hz}$ were used. Besides a die of $4 \mathrm{~mm}$ diameter. After extrusion the extruded

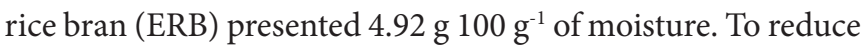

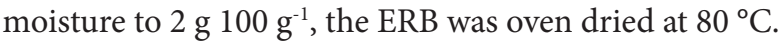

The simplex design was employee (Barros et al., 2001), with five runs and two replications at the central point. The tree

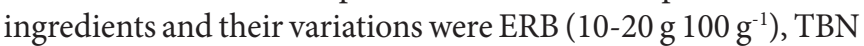

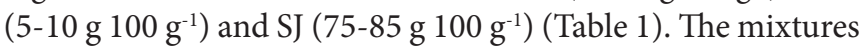

Table 1. Simplex design used to prepared the sugar cane candies ("rapaduras") with sugar cane juice (SJ), extruded rice bran (ERB) and toasted baru nut (TBN), real concentrations and pseudo-components values.

\begin{tabular}{cccccccc}
\hline \multirow{2}{*}{ Run } & \multicolumn{3}{c}{ Real concentration $\left({\left.\mathrm{g} 100 \mathrm{~g}^{-1}\right)}\right.$} & & \multicolumn{3}{c}{ Pseudo-component } \\
\cline { 2 - 3 } \cline { 7 - 8 } & ERB & TBN & SJ & & ERB & TBN & SJ \\
\hline R1 & 10 & 5 & 85 & & 0 & 0 & 1 \\
R2 & 20 & 5 & 75 & & 1 & 0 & 0 \\
R3 & 10 & 10 & 80 & & 0 & 0.5 & 0.5 \\
R4 & 15 & 10 & 75 & & 0.5 & 0.5 & 0 \\
R5 & 13.75 & 7.50 & 78.75 & & 0.375 & 0.25 & 0.375 \\
R5 $_{(2)}$ & 13.75 & 7.50 & 78.75 & & 0.375 & 0.25 & 0.375 \\
R5 $_{(3)}$ & 13.75 & 7.50 & 78.75 & & 0.375 & 0.25 & 0.375 \\
\hline ERB + TBN + SJ $=100$ or 1. & & & & &
\end{tabular}

$\mathrm{ERB}+\mathrm{TBN}+\mathrm{SJ}=100$ or 1. to prepare the "rapaduras" were calculates by Statistica software (MicroStat, Statistica 7.0, Tulsa, USA).

Experimental sugar cane candies were processed on Santa Rita Farm. The SJ was sieved to separate impurities, and concentrated in a copper recipient on direct fire. The impurities that floated were collected with a ladle throughout this processing step. When SJ attained $80^{\circ} \mathrm{C}$, it was vigorously shaken for air incorporation and texture improvement. The concentration process with constant shaking continued up to $120^{\circ} \mathrm{C}$, when the concentrated sugar cane juice was moved to another recipient, and ERB and TBN were incorporated, blended, placed in into molds of $25 \mathrm{~g}$, cooled, and packed in plastic film until the analysis days.

\subsection{Physical and chemical characteristics}

The particles size was determined in granulometer (Produtest, T, São Paulo, Brazil), according to the recommended method by Dias \& Leonel (2006). The luminosity, chroma $\mathrm{a}^{\star}$ and chroma $\mathrm{b}^{\star}$ of the "rapaduras" were read by a colorimeter (ColorQuest II, HunterLab, Reston, Canada). Hardness was read by a texturometer (TA, XT2, Halesmere, United Kingdom), with distance of $18 \mathrm{~mm}$, test speed of $2 \mathrm{~mm} \mathrm{~s}^{-1}, 0.98 \mathrm{~N}$ of force and HDP/BSK knife. The lipids, protein, ash, soluble, insoluble and total dietary fiber contents of the raw materials and "rapaduras" were obtained by methods of Association of Official Analytical Chemists (2012). The total carbohydrate was determined by difference method (Equation 1). The total energy was estimated with the conversion factors of Atwater (Brasil, 2003). The microbiological and sensory analysis were carried out on the "rapadura" choosed by the result of the desirability test.

Total carbohydrate $=100-($ mass in $g[$ protein + fat + water + ash $]$ in $100 \mathrm{~g}$ of food $)$

\subsection{Microbiological analysis and sensory acceptance}

The Staphylococcus aureus, thermotolerant and total Coliforms, Bacillus cereus, molds \& yeasts counts and the presence or absence of Salmonella spp were determined by methods recommended by Food and Drug Administration (2001). Texture, appearance, odor and flavor were analyzed on a sensory laboratory by a nine point hedonic scale (1: dislike extremely, 5: neither like nor dislike and 9: like extremely), using design of randomized blocks. Negative, maybe or positive purchase intent was determined too (Dutcosky, 2015). Sensory acceptance was carry-out by fifty tasters, 34 women and 16 men, with high educational formation and sensory analysis experience (94\%), in individual cabins. The samples, cut into $30 \mathrm{~mm} \times 30 \mathrm{~mm}$ pieces, were offered on disposable plastic dishes in a sequential monadic form and completely randomized design. The acceptance test was approved by the Ethics Committee.

\subsection{Statistical analyses}

The adjusted models were evaluated by variance analysis ( $\mathrm{p} \leq 0.10)$, and with "Response Desirability Profiling" function (MicroStat, Statistica 7.0, Tulsa, USA). For the choice of the best formulation was considered the highest values of luminosity (lighter), protein, ash, total dietary fiber and lipids (with more balanced nutritional value), and lowest value of hardness (closer 
to the value obtained for traditional sugar cane). The means of the sensorial attributes were compared by the Tukey test $(\mathrm{p} \leq 0.05)$.

\section{Results and discussion}

\subsection{Particle sizes and proximal composition of raw material}

The ERB presented $80.02 \%$ of the particles retained in the $2.83 \mathrm{~mm}$ sieve, $8.91 \%$ on the background plate, and $11.07 \%$ distributed between 2.19, 1.68, 1.19 and $0.54 \mathrm{~mm}$ sieves, whilst for the TBN, $44.01 \%$ of particles stopped on the $2.83 \mathrm{~mm}$ sieve, $17.97 \%$ on the $2.91 \mathrm{~mm}$ sieve, $10.29 \%$ on the bottom plate, and the rest on the other sieves (Figure 1).

SJ did not present in its composition lipids, dietary soluble and insoluble fiber. Protein and ash contents, and total energy value of SJ were lower than in the other ingredients (Table 2). The ash content of ERB was 3.2 times higher than in TBN. In contrast, the protein and lipids contents and total energy value of TBN were $85 \%, 120 \%$ and $30 \%$ higher than ERB. Carbohydrates were higher in SJ then in the other components (ERB and TBN).

Lacerda et al. (2009) reported for $100 \mathrm{~g}$ of ERB values of $7.63 \mathrm{~g}$ ash, $13.46 \mathrm{~g}$ protein, $27.72 \mathrm{~g}$ lipid, $38.84 \mathrm{~g}$ carbohydrates and $16.35 \mathrm{~g}$ TDF. Sousa et al. (2011) reported for $100 \mathrm{~g}$ of baru nut on wet basis $3.18 \mathrm{~g}$ ash, $29.92 \mathrm{~g}$ protein, $41.95 \mathrm{~g}$ lipids, $12.25 \mathrm{~g}$

Table 2. Total energy value and proximal composition (dry matter basis) of the sugar cane juice (SJ), toasted baru nuts (TBN) and extruded rice bran (ERB).

\begin{tabular}{lrrc}
\hline \multicolumn{1}{c}{ Parameter } & \multicolumn{1}{c}{ ERB } & \multicolumn{1}{c}{ TBN } & \multicolumn{1}{c}{ SJ } \\
\hline Ash $^{(1)}$ & $9.79 \pm 0.04^{\mathrm{a}}$ & $3.03 \pm 0.04^{\mathrm{b}}$ & $0.34 \pm 0.01^{\mathrm{c}}$ \\
Protein $^{(1)}$ & $15.80 \pm 0.13^{\mathrm{b}}$ & $29.18 \pm 0.39^{\mathrm{a}}$ & $0.06 \pm 0.00^{\mathrm{c}}$ \\
Lipids $^{(1)}$ & $17.69 \pm 0.07^{\mathrm{b}}$ & $39.08 \pm 1.81^{\mathrm{a}}$ & $0.00^{\mathrm{c}}$ \\
Total carbohydrate $^{(1)}$ & $56.71 \pm 0.17^{\mathrm{b}}$ & $28.70 \pm 1.43^{\mathrm{c}}$ & $99.6 \pm 0.01^{\mathrm{a}}$ \\
Total dietary fiber $^{(1)}$ & $12.69 \pm 0.06^{\mathrm{b}}$ & $16.37 \pm 0.28^{\mathrm{a}}$ & $0.00^{\mathrm{c}}$ \\
Soluble dietary fiber $^{(1)}$ & $2.28 \pm 0.28^{\mathrm{b}}$ & $2.72 \pm 0.14^{\mathrm{a}}$ & $0.00^{\mathrm{c}}$ \\
Insoluble dietary fiber $^{(1)}$ & $10.41 \pm 0.22^{\mathrm{b}}$ & $13.65 \pm 0.14^{\mathrm{a}}$ & $0.00^{\mathrm{c}}$ \\
Total energy value $^{(2)}$ & $449.28 \pm 0.25^{\mathrm{b}}$ & $583.30 \pm 9.12^{\mathrm{a}}$ & $398.62 \pm 0.05^{\mathrm{c}}$ \\
\hline
\end{tabular}

Means in the same line with different letters differ significantly (Tukey Test; $p \leq 0.05$ ); means followed by standard deviations; ${ }^{(1)} \mathrm{g} 100 \mathrm{~g} \mathrm{~g}^{-1}{ }^{(2)} \mathrm{kcal} \mathrm{g}^{-1}$. carbohydrates and $9.21 \mathrm{~g}$ TDF, values similar to those of this research, except in relation to total dietary fiber. One hundred grams of sugar cane juice (wet basis) had $0.3 \mathrm{~g}$ ash, $0.3 \mathrm{~g}$ protein, $0.1 \mathrm{~g}$ lipid and $20.5 \mathrm{~g}$ carbohydrates, and $82 \mathrm{kcal}$ (Instituto Brasileiro de Geografia e Estatística, 1999). Variations in the composition of the raw materials can be justified by differences among cultivars, seasons and harvesting site (Carvalho \& Bassinello, 2006).

\subsection{Characterization of sugar cane candies}

Luminosity, hardness, chemical composition and total energy value for the standard sugar cane candy and for those made with SJ, TBN and ERB are presented in Table 3. Statistical differences for ash, protein, lipids and total dietary fiber were significant $(\mathrm{p}<0.05)$, while luminosity $\left(\mathrm{L}^{*}\right)$ and hardness were significant ( $\mathrm{p} \leq 0.10$ ), and explained $89-99 \%$ of the responses, and lack of fit was not significant (Table 4). Differences were not calculated for total carbohydrates and total energy because the values were only estimated.

There was a trend of higher luminosity values (62) is in the area of the graph which includes points A, B and 4 (Figure 2A). Lower values of luminosity $L^{*}(41)$ includes formulations with

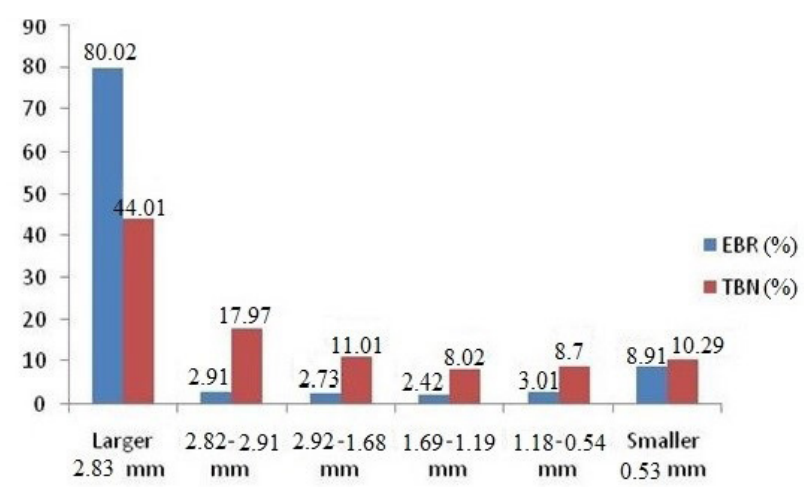

Figure 1. Particle size distribution of extruded rice bran (EBR) and toasted baru nut (TBN) (Dypteryx alata Vog.).

Table 3. Physicochemical characteristics of sugar cane candies "rapaduras" (R) formulated with sugar cane juice (SJ), extruded rice bran (ERB) and toasted baru nuts (TBN).

\begin{tabular}{|c|c|c|c|c|c|c|c|c|}
\hline Parameter & Standard $^{(7)}$ & R1 & R2 & R3 & $\mathrm{R} 4$ & $\mathrm{R}_{(1)}$ & $\mathrm{R}_{(2)}$ & $\mathrm{R}_{(3)}$ \\
\hline Luminosity & $47.57 \pm 3.00^{\mathrm{d}}$ & $48.33 \pm 0.40^{\mathrm{d}}$ & $41.25 \pm 0.60^{\mathrm{e}}$ & $53.96 \pm 1.30^{c}$ & $63.47 \pm 0.70^{\mathrm{a}}$ & $53.22 \pm 1.50^{c}$ & $59.79 \pm 0.60^{\mathrm{b}}$ & $55.79 \pm 1.70^{c}$ \\
\hline Hardness $^{(1)}$ & $19.81 \pm 3.00^{\mathrm{d}}$ & $26.10 \pm 2.60^{\mathrm{a}}$ & $24.45 \pm 3.70^{\mathrm{b}}$ & $26.15 \pm 4.90^{\mathrm{a}}$ & $20.35 \pm 2.20^{\mathrm{d}}$ & $22.53 \pm 2.10^{c}$ & $21.06 \pm 2.50^{c d}$ & $21.09 \pm 1.70^{\mathrm{cd}}$ \\
\hline $\operatorname{Ash}^{(2)}$ & $1.56 \pm 0.04^{\mathrm{e}}$ & $2.26 \pm 0.10^{\mathrm{d}}$ & $3.27 \pm 0.06^{\mathrm{a}}$ & $2.62 \pm 0.02^{c}$ & $2.93 \pm 0.04^{\mathrm{b}}$ & $2.71 \pm 0.02^{\mathrm{bc}}$ & $2.89 \pm 0.02^{\mathrm{bc}}$ & $2.84 \pm 0.10^{\mathrm{bc}}$ \\
\hline Protein $^{(2)}$ & $0.28 \pm 0.01^{\mathrm{d}}$ & $3.28 \pm 0.10^{c}$ & $5.47 \pm 0.02^{\mathrm{b}}$ & $5.85 \pm 0.03^{\mathrm{a}}$ & $5.90 \pm 0.10^{\mathrm{a}}$ & $5.19 \pm 0.24^{\mathrm{b}}$ & $5.39 \pm 0.20^{\mathrm{b}}$ & $5.25 \pm 0.10^{\mathrm{b}}$ \\
\hline Lipids $^{(2)}$ & $0.00 \pm 0.00^{e}$ & $3.87 \pm 0.00^{d}$ & $5.80 \pm 0.04^{c}$ & $7.11 \pm 0.30^{\mathrm{b}}$ & $7.67 \pm 0.40^{\mathrm{a}}$ & $6.21 \pm 0.30^{c}$ & $6.80 \pm 0.30^{\mathrm{b}}$ & $5.99 \pm 0.10^{c}$ \\
\hline Carbohydrates $^{(2)}$ & 98.16 & 90.67 & 85.46 & 84.42 & 83.50 & 85.90 & 84.91 & 85.92 \\
\hline $\operatorname{TDF}^{(2,3)}$ & $0.00 \pm 0.00^{\mathrm{f}}$ & $1.47 \pm 0.00^{\mathrm{e}}$ & $2.67 \pm 0.10^{\mathrm{a}}$ & $2.01 \pm 0.10^{\mathrm{d}}$ & $2.58 \pm 0.00^{\mathrm{b}}$ & $2.40 \pm 0.10^{c}$ & $2.44 \pm 0.00^{c}$ & $2.45 \pm 0.10^{c}$ \\
\hline $\mathrm{SDF}^{(2,4)}$ & $0.00 \pm 0.00^{\mathrm{d}}$ & $0.29 \pm 0.00^{c}$ & $0.50 \pm 0.03^{\mathrm{a}}$ & $0.36 \pm 0.10^{\mathrm{b}}$ & $0.43 \pm 0.00^{\mathrm{a}}$ & $0.36 \pm 0.04^{\mathrm{b}}$ & $0.38 \pm 0.00^{\mathrm{b}}$ & $0.37 \pm 0.00^{\mathrm{b}}$ \\
\hline $\operatorname{IDF}^{(2,5)}$ & $0.00 \pm 0.00^{\mathrm{e}}$ & $1.18 \pm 0.00^{\mathrm{d}}$ & $2.17 \pm 0.10^{\mathrm{a}}$ & $1.65 \pm 0.05^{c}$ & $2.15 \pm 0.00^{\mathrm{a}}$ & $2.04 \pm 0.00^{\mathrm{b}}$ & $2.06 \pm 0.00^{\mathrm{b}}$ & $2.07 \pm 0.00^{\mathrm{b}}$ \\
\hline Total energy value ${ }^{(6)}$ & 393.76 & 409.02 & 415.94 & 425.05 & 426.62 & 420.22 & 422.47 & 418.61 \\
\hline
\end{tabular}

Means in the same line with different letters differ significantly (Tukey Test; $\mathrm{p} \leq 0.05$ ); means followed by standard deviations; ${ }^{(1)} \mathrm{Newtons} ;{ }^{(2)} \mathrm{g} 100 \mathrm{~g}{ }^{-1}$; ${ }^{(3)} \mathrm{TDF}=$ Total dietary fiber;

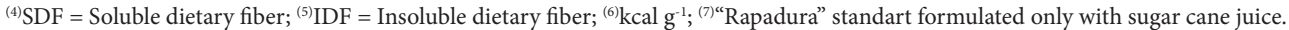


Table 4. Fitted polynomial models for luminosity, hardness, lipids, protein, total dietary fiber and ashes $\left(\mathrm{y}_{\mathrm{n}}\right)$ in function of the extruded rice brain $\left(\mathrm{x}_{1}\right)$, toasted baru nuts $\left(\mathrm{x}_{2}\right)$ and sugar cane juice $\left(\mathrm{x}_{3}\right)$ (coded levels), coefficient of determination $\left(\mathrm{R}^{2}\right)$, significance level ( $\left.\mathrm{p}\right)$ and lack of fit (LF).

\begin{tabular}{lcccc}
\hline \multicolumn{1}{c}{ Parameter } & Model & $\mathrm{p}$ & $\mathrm{LF}$ & $\mathrm{R}^{2}$ \\
\hline Luminosity & $y_{1}=42.1 \mathrm{x}_{1}+59.3 \mathrm{x}_{2}+49.8 \mathrm{x}_{3}+58.0 \mathrm{x}_{1} \mathrm{x}_{2}$ & 0.059 & 0.38 & 0.89 \\
Hardness & $y_{2}=24.5 \mathrm{x}_{1}+26.2 \mathrm{x}_{2}+26.1 \mathrm{x}_{3}-19.9 \mathrm{x}_{1} \mathrm{x}_{2}-14.8 \mathrm{x}_{1} \mathrm{x}_{3}$ & 0.076 & 1.00 & 0.96 \\
Ashes & $y_{3}=3.3 \mathrm{x}_{1}+2.8 \mathrm{x}_{2}+2.3 \mathrm{x}_{3}$ & 0.04 & 0.48 & 0.94 \\
Protein & $y_{4}=5.6 \mathrm{x}_{1}+8.4 \mathrm{x}_{2}+3.4 \mathrm{x}_{3}-3.6 \mathrm{x}_{1} \mathrm{x}_{2}$ & 0.010 & 0.08 & 0.97 \\
Lipids & $y_{5}=5.8 \mathrm{x}_{1}+10.1 \mathrm{x}_{2}+4.01 \mathrm{x}_{3}$ & 0.003 & 0.70 & 0.94 \\
Total dietary fiber & $y_{6}=2.6 \mathrm{x}_{1}+2.5 \mathrm{x}_{2}+1.5 \mathrm{x}_{3}+1.8 \mathrm{x}_{1} \mathrm{x}_{3}$ & 0.000 & 0.55 & 0.99 \\
\hline
\end{tabular}
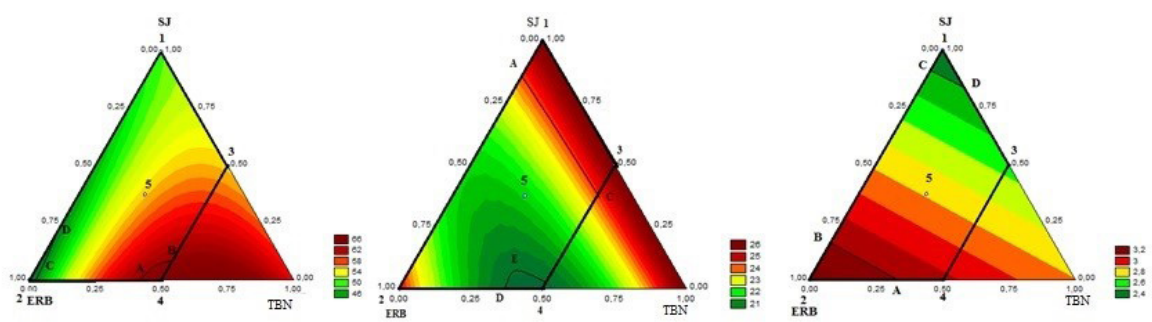

Figure 2. Luminosity (A), hardness (B) and ash content (C) of sugar cane candies "rapaduras" (R) as function of the toasted baru nut (TBN), extruded rice bran (ERB) and sugar cane juice (SJ) level.

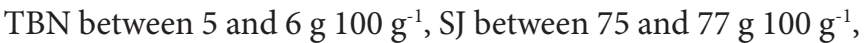

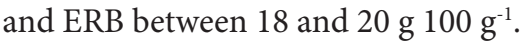

SJ is responsible for the caramelization (the reaction that happens with the heating of the sucrose), flavor and dark color of the "rapaduras". Therefore, the addition of solids components (TBN and ERB) lightens the color of the candy in comparison with the control candy (Damodaran et al., 2010), and the formulations with higher concentrations of SJ.

The area included between the points A, C, 1 and 3 (Figure 2B) had values of hardness (above $25 \mathrm{~N}$ ), higher than those found in the standard "rapadura" (Table 3). Thus, the hardest "rapaduras" were formulated with 10-15 g $100 \mathrm{~g}^{-1}$ of ERB and 75-80 g $100 \mathrm{~g}^{-1}$ of SJ. In study conducted by Silva et al. (2016) that evaluated the physicochemical characteristics of "rapaduras" formulated with different concentrations of extruded rice bran, sugar cane and juice roasted peanuts, a crunch grain with a texture similar to baru, the hardest sugar cane candies were the ones that contained 18.6-20 $\mathrm{g} 100 \mathrm{~g}^{-1}$ of extruded rice bran,

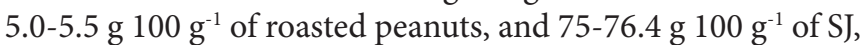
probably due to differences in texture between the nuts.

During the hardness tests it was possible to note that when the probe reached a nut it required higher compression force, but when it reached an area with mostly ERB less compression power was required. As the mass of "rapaduras" was not structured in these areas, it was as if there were empty of spaces between the solidified SJ (hard) and the ERB, enabling easer rupture of the sample.

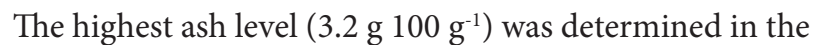
area formed by points A, B and 2 (Figure 2C) and the lowest ash

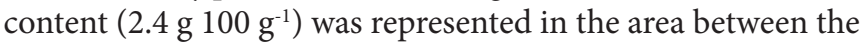
points C, D and 1. Therefore, the largest amount of ash was in "rapadura" with the maximum amounts of ERB and minimal SJ. In their experimental sugar cane candy, Silva et al. (2016) obtained higher ash content with higher amounts of the extruded rice bran and a lower roasted peanut content. An increase in ashes was observed in formulated "rapaduras", which reiterates the importance of including ERB, TBN or roasted peanut, as possible source of minerals. In their papers on the composition of pure sugar cane sweetener, Maria (2013) and Guerra \& Mujica

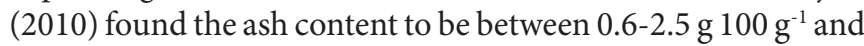

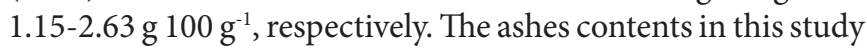
(Table 2) were between 2.26-3.27 g $100 \mathrm{~g}^{-1}$.

The highest protein content was found in the formulations R3 and R4, which had the highest values of TBN (Table 3), as demonstrated in Figure $3 \mathrm{~A}$ through the area limited by points $\mathrm{A}, \mathrm{B}, 3$ and 4 . TBN was the component with the highest protein content (Table 2), Silva et al. (2016) also obtained the largest amount of protein with higher contents of extruded rice bran and a higher amount of roasted peanut.

The highest level of lipid was verified in the lower concentrations of SJ, and higher of TBN and ERB and, formulation R4, in the area delimited by 3, 4, A and B points (Figure 3B).

The lowest content of lipid was determined in the area limited by $1, . \mathrm{C}$ and $\mathrm{D}$ points. The lipids in the "rapaduras" were from TBN, which contains high amounts of lipids (Table 2), while the standard "rapadura" did not contain lipids. Silva et al. (2016) also obtained the highest level of lipids with the formulation with the highest amount of roasted peanut.

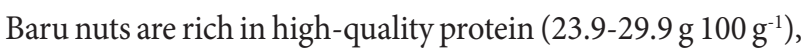

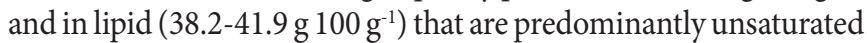

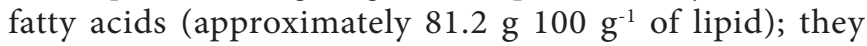
also have high concentrations of phytate and tannins 
$\left(1073.6 \pm 114.9\right.$ and $72.2 \pm 12.5 \mathrm{mg} 100 \mathrm{~g}^{-1}$, respectively) Consumption of baru nut protects biological tissues against iron-induced oxidative stress, and the phytic acid may be partially responsible for this protective effect (Sousa et al., 2011; Siqueira et al., 2012).

Dietary supplementation of mildly hypercholesterolemic subjects with baru nuts improved serum lipid parameters, so this product might be included in diets for reducing the risk of cardiovascular diseases (Bento et al., 2014).

The highest level of total dietary fiber was observed with the higher concentrations of TBN and ERB and lower of SJ, formulation R2 (Table 3), and visualized in Figure 3C, between the A, B and 2 points. The same result was obtained by Silva et al. (2016), since the highest level of total dietary fiber in "rapadura" was the one with the maximum amount of extruded rice bran and roasted peanut, and minimum amounts of SJ.

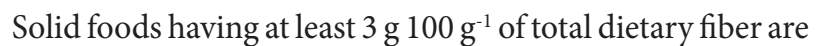
classified as source of dietary fiber (Brasil, 2003). The formulation $\mathrm{R} 2$ had the highest total dietary fiber content $\left(2.67 \mathrm{~g} 100 \mathrm{~g}^{-1}\right)$, $89 \%$ of the amount considered a standard by the legislation.
The highest values of total dietary fiber, protein, lipids and ash obtained in the "rapaduras" are due to the maximum addition of ERB and TBN.

The result of the desirability profile graphic for selecting the formulated "rapadura" with high values of luminosity (lighter), protein, ash, total dietary fiber and lipids (with more balanced nutritional value), and lowest value of hardness (closer to the value obtained for traditional sugar cane), indicated the pseudo-components of ERB, TBN and SJ as 0.5, 0.5, 0 (sample R4)

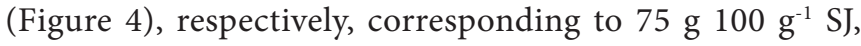

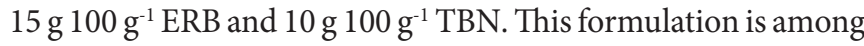
those with the lowest amount of SJ and higher amounts of TBN, which is responsible for the increase in nutrients present in the formulated "rapadura".

\subsection{Microbiological risk}

The selected "rapadura" had low count of Staphylococcus aureus, Bacillus cereus, total coliforms, thermotolerant coliforms, molds and yeasts (Table 5). All parameters showed values below
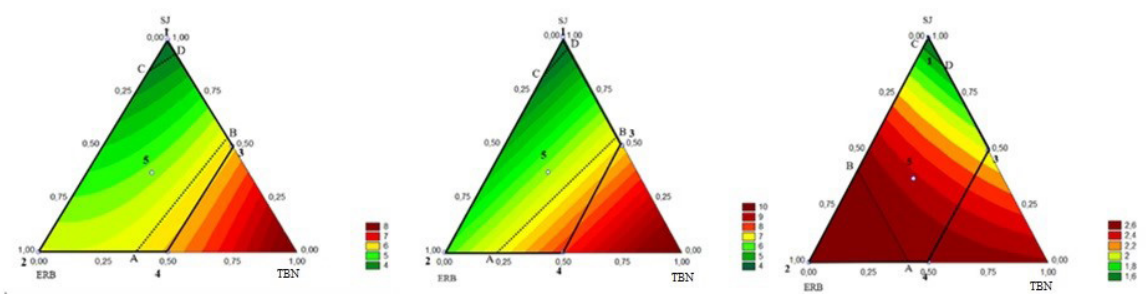

Figure 3. Protein (A), lipid (B) and total dietary fiber (C) of sugar cane candies "rapaduras" (R) as function of the toasted baru nut (TBN), extruded rice bran (ERB) and sugar cane juice (SJ) level.

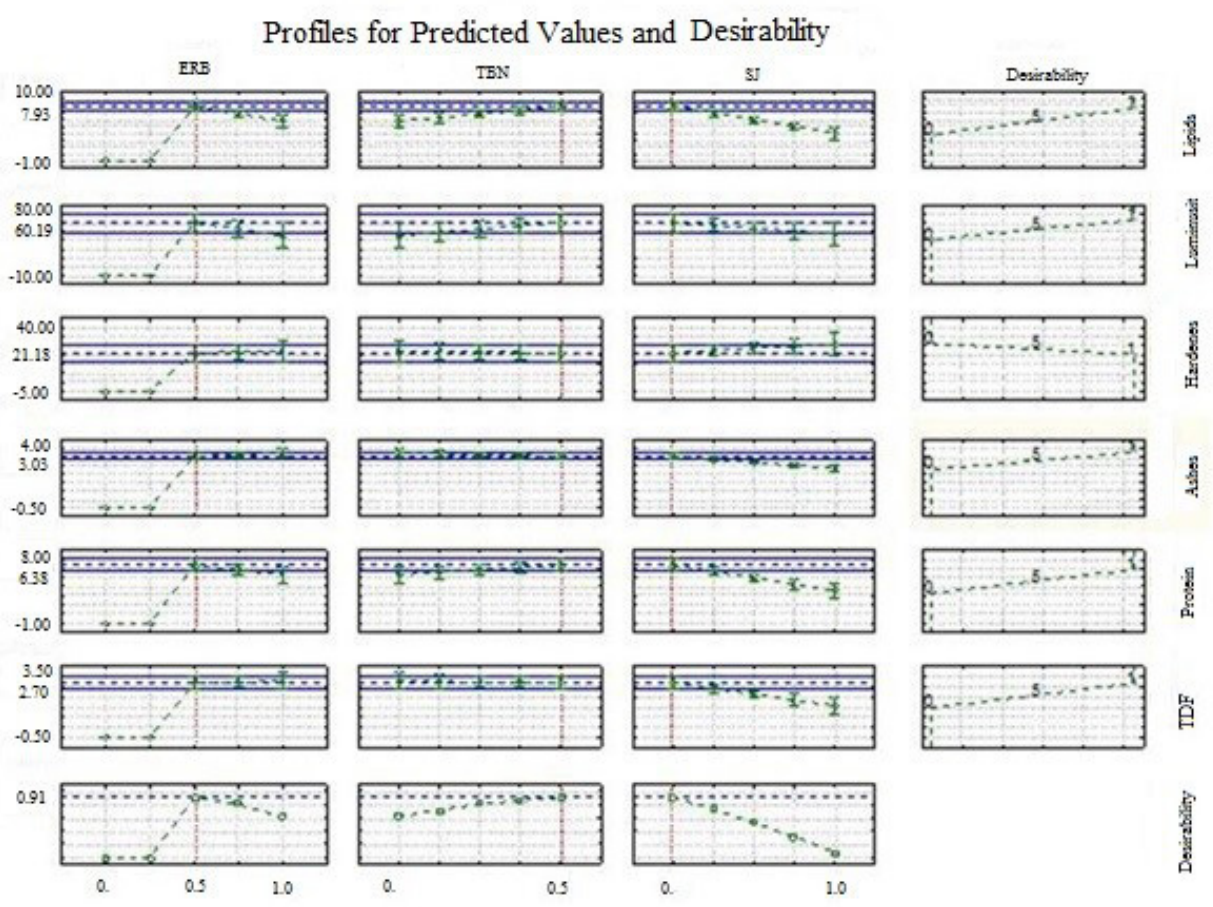

Figure 4. Profiles for predicted values of desirability. 
Table 5. Results of microbiological analysis of the sugar cane candy "rapadura" chosen by the desirability test.

\begin{tabular}{lcc}
\hline \multicolumn{1}{c}{ Parameter } & $\begin{array}{c}\text { Sugar cane } \\
\text { candy }\end{array}$ & $\mathrm{MAV}^{*}$ \\
\hline Total coliforms $\left(\mathrm{MPN} \mathrm{g}^{-1}\right)$ & $10^{2}$ & $\mathrm{NE}$ \\
Thermotolerant coliforms $45^{\circ} \mathrm{C}\left(\mathrm{MNP} \mathrm{g}^{-1}\right)$ & $<10$ & $1.0 \times 10^{1}$ \\
Molds and yeasts $\left(\mathrm{CFU} \mathrm{g}^{-1}\right)$ & $<100$ & $\mathrm{NE}$ \\
Staphylococcus aureus $\left(\mathrm{CFU} \mathrm{g}^{-1}\right)$ & $<100$ & $1.0 \times 10^{3}$ \\
Bacillus cereus $\mathrm{g}^{-1}$ & $<100$ & $5.0 \times 10^{3}$
\end{tabular}

Salmonella sp g ${ }^{-1} \quad$ absence in $25 \mathrm{~g}$ absence in $25 \mathrm{~g}$

${ }^{*} \mathrm{MAV}=$ maximum allowed value by National Health Surveillance Agency (ANVISA), Resolution RDC no. 12 of January 2, 2001 (Brasil, 2001); NE = limits not established by Anvisa; $\mathrm{CFU}=$ colony forming units; $\mathrm{MPN}=$ more probable number.

the limit stablished by Brazilian legislation and do not present risk to the consumers (Brasil, 2001).

The raw materials used for the production of "rapaduras" had low microbial count and that the processing occurred in suitable hygienic-sanitary conditions. Wojtczak et al. (2012) reported that the presence of microorganisms in raw cane sugar may be caused by microbiological contamination both during cane processing and during transport and storage.

\subsection{Sensory analysis}

The selected "rapadura" received an average score of 7.74 for appearance, 7.68 for flavor, 7.56 for aroma, and 7.66 for texture, with classification between 'like very much' and 'like moderately'. The results stayed above the acceptance rate set indicated by Dutcosky (2015), that recommended to take into consideration 7.0 as the minimum score for the acceptance of a product.

Of the tasters, $58 \%$ said that would definitely buy the selected "rapadura", 24\% would probably buy, 16\% maybe would buy, $2 \%$ possibly would not buy and no one said that they certainly would not buy. Most of the judges (98\%) expressed some interest in buying the "rapadura", which shows its high acceptance level, allowed that it would be a great option for market, because it has better nutritional features than the traditional standard "rapadura".

\section{Conclusion}

Ash, protein, lipids, dietary soluble, insoluble and total dietary fiber contents, and total energy value of sugar cane juice were lower than in the other ingredients. The hardness values of the experimental sugar cane candies were close to the traditional product, while protein, lipids, and total dietary fiber were above the values of the traditional product. The selected formulation of sugar cane candy combining extruded rice bran, toasted baru nut and the sugar cane juice had low microbiological risk and good sensory acceptance. The product has technological potential, with sensory and nutritional advantages, and can be an alternative to add value to rice by-product and nuts from areas of forest conservation.

\section{Acknowledgements}

To CAPES and Fapegfor fellowship support, and UEL for partnership.

\section{References}

Association of Official Analytical Chemists - AOAC. (2012). Official methods of analysis (19th ed.). Washington: AOAC.

Barros, B. B. No., Scarminio, I. S., \& Bruns, R. E. (2001). Como fazer experimentos: pesquisa e desenvolvimento na ciência e na indústria. Campinas: Unicamp.

Bento, A. P. N., Cominetti, A., Simões, B. Fo., \& Naves, M. M. V. (2014). Baru almond improves lipid profile in mildly hypercholesterolemic subjects: a randomized, controlled, crossover study. Nutrition, Metabolism, and Cardiovascular Diseases, 24(12), 1330-1336. http:// dx.doi.org/10.1016/j.numecd.2014.07.002. PMid:25149894.

Brasil, Agência Nacional de Vigilância Sanitária - ANVISA. (2001, January 10). Regulamento Técnico sobre padrões microbiológicos para alimentos (Resolução RDC no 12, de 2 de janeiro de 2001). Diário Oficial [da] República Federativa do Brasil.

Brasil, Agência Nacional de Vigilância Sanitária - ANVISA. (2003, December 26). Regulamento Técnico sobre rotulagem nutricional de alimentos embalados (Resolução RDC n 360, de 23 de dezembro de 2003). Diário Oficial [da] República Federativa do Brasil.

Carvalho, J. L. V., \& Bassinello, P. Z. (2006). Aproveitamento industrial. In A. B. Santos, L. F. Stone \& N. R. A. Vieira (Eds.), A cultura do arroz no Brasil (2. ed., Cap. 24, pp. 1007-1047). Santo Antônio de Goiás: Embrapa Arroz e Feijão.

Damodaran, S., Parkin, K. L., \& Fennema, O. R. (2010). Química de alimentos de Fennema (4. ed). Porto Alegre: Artmed.

Dias, L. T., \& Leonel, M. (2006). Physicochemical characteristics of cassava flours from different regions of Brazil. Ciência e Agrotecnologia, 30(4), 692-700. http://dx.doi.org/10.1590/S1413-70542006000400015.

Dutcosky, S. D. (2015). Análise sensorial de alimentos. Curitiba: Champagnat.

Food and Drug Administration - FDA. (2001). Bacteriological analytical manual (1st ed.). Arlington: Association of Official Analytical Chemists.

Freitas, J. B., \& Naves, M. M. V. (2010). Chemical composition of nuts and edible seeds and their relation to nutrition and health. Revista de Nutrição, 23(2), 269-279. http://dx.doi.org/10.1590/S141552732010000200010.

Friedman, M. (2013). Rice brans, rice bran oils, and rice hulls: composition, food and industrial uses, and bioactivities in humans, animals, and cells. Journal of Agricultural and Food Chemistry, 61 (45), 10626-10641. http://dx.doi.org/10.1021/jf403635v. PMid:24175575.

Guerra, M. J., \& Mujica, M. V. (2010). Physical and chemical properties of granulated cane sugar "panelas". Food Science and Technology, 30(1), 250-257. http://dx.doi.org/10.1590/S0101-20612010005000012.

Gul, K., Yousuf, B., Singh, A. K., Singh, P., \& Wani, A. A. (2015). Rice bran: nutritional values and its emerging potential for development of functional food: a review. Bioactive Carbohydrates and Dietary Fibre, 6(1), 24-30. http://dx.doi.org/10.1016/j.bcdf.2015.06.002.

Instituto Brasileiro de Geografia e Estatística - IBGE. (1999). Estudo nacional da despesa familiar: tabela de composição de alimentos (5. ed.). Rio de Janeiro: Varela.

Lacerda, D. B. C. L., Soares, M. S. Jr., Bassinello, P. Z., Caliari, M., \& Castro, M. V. L. (2013). The kinetics of lipase activity and hydrolytic rancidity of raw, parboiled, and extruded rice bran during storage. 
Food Science and Technology, 33(2), 376-381. http://dx.doi.org/10.1590/ S0101-20612013005000053.

Lacerda, D. B. C. L., Soares, M. S. Jr., Bassinello, P. Z., Siqueira, A. B. S., \& Koakuzu, S. N. (2009). Qualidade de biscoitos elaborados com farelo de arroz extrusado em substituição a farinha de trigo e fécula de mandioca. Archivos Latinoamericanos de Nutricion, 59(2), 199-205. PMid:19719018.

Liu, L., Wen, W., Zhang, R., Wei, Z., Deng, Y., Xiao, J., \& Zhang, M. (2017). Complex enzyme hydrolysis releases antioxidative phenolics from rice bran. Food Chemistry, 214(1), 1-8. PMid:27507440.

Maranhão, P. A., Kraemer-Aguiar, L. G., Oliveira, C. L., Kuschnir, M. C., Vieira, Y. R., Souza, M. G., Koury, J. C., \& Bouskela, E. (2011). Brazil nuts intake improves lipid profile, oxidative stress and microvascular function in obese adolescents: a randomized controlled trial. Nutrition \& Metabolism, 8(1), 32. PMid:21619692.

Maria, G. (2013). Panela: the natural nutritional sweetener. Agro Food Industry Hi-Tech, 24(6), 44-48.

Marin, A. M., Siqueira, E. M., \& Arruda, S. F. (2009). Minerals, phytic acid and tannin contents of 18 fruits from the Brazilian savanna. International Journal of Food Sciences and Nutrition, 60(7, Suppl 7), 180-190. http://dx.doi.org/10.1080/09637480902789342. PMid:19353365.

Rodriguez, G., Garcia, H., Diaz, Z. R., \& Santacoloma, P. (2007). Panela production as a strategy for diversifying incomes in rural area of Latin
America. Rome: Agricultural Management, Marketing and Finance Service (AGSF), Agricultural Support Systems Division, FAO.

Silva, C. C. F., Caliari, M., Soares, M. S. Jr., Marques, R. C. D., Beleia, A. P., \& Garcia, M. C. (2016). Physicochemical and sensory properties of sugar cane candies with roasted peanut and extruded rice bran. Journal of Food and Nutrition Research, 4(3), 163-169.

Silva, F. S., Cristale, J., Ribeiro, M. L., \& Marchi, M. R. R. (2011). Polycyclic aromatic hydrocarbons (PAHs) in raw cane sugar (rapadura) in Brazil. Journal of Food Composition and Analysis, 24(3), 346-350. http://dx.doi.org/10.1016/j.jfca.2010.08.012.

Siqueira, E. M. A., Marin, A. M. F., Cunha, M. S. B., Fustinoni, A. M., Sant'Ana, L. P., \& Arruda, S. F. (2012). Consumption of baru seeds [Dipteryx alataVog.], a Brazilian savanna nut, prevents iron-induced oxidative stress in rats. Food Research International, 45(1), 427-433. http://dx.doi.org/10.1016/j.foodres.2011.11.005.

Sousa, A. G. O., Fernandes, D. C., Alves, A. M., Freitas, J. B., \& Naves, M. M. V. (2011). Nutritional quality and protein value of exotic nuts and nut from the Brazilian Savanna compared to peanut. Food Research International, 44(7), 2319-2325. http://dx.doi.org/10.1016/j. foodres.2011.02.013.

Wojtczak, M., Biernasiak, J., \& Papiewska, A. (2012). Evaluation of microbiological purity of raw and refined white cane sugar. Food Control, 25(1), 136-139. http://dx.doi.org/10.1016/j.foodcont.2011.10.031. 